\title{
Available Status of Soil as Influenced by Validation of Fertilizer Prescription Equations of Kharif Grain Maize on Different Soil Orders
}

\author{
Ghodke Pallavi Dipak*, Kadlag Ashok Dattatray and Kokre Vishwajit Gorakhnath
}

Department of Soil Science and Agriculture Chemistry, Mahatma Phule Krishi Vidyapeeth, Rahuri- 413 722, Dist. Ahmednagar, Maharashtra, India

*Corresponding author

\begin{tabular}{|l|}
\hline Ke y w o r d s \\
$\begin{array}{l}\text { Soil, Validation of } \\
\text { fertilizer, Soil } \\
\text { orders, Kharif grain } \\
\text { maize }\end{array}$ \\
\hline Article Info \\
\hline $\begin{array}{l}\text { Accepted: } \\
\text { 08 June } 2018 \\
\text { Available Online: } \\
\text { 10 July } 2018\end{array}$ \\
\hline
\end{tabular}

\section{Introduction}

The present production of fertilizer nutrients of the country is not enough to meet the total plant nutrient requirement for the expected food grain production. In recent years the imbalanced and inadequate fertilizer use coupled with low use efficiency of other
The experiment was conducted on Inceptisol (Pather series, Vertic Haplustepts) during the year 2009-10 on experimental farm of the Soil Test Crop Response Correlation Project, M.P.K.V Rahuri for evaluation of a scientific basis for calculating the "Nutrient requirement of maize by conjoint use of FYM and chemical fertilizers based on targeted yield approach on Inceptisol". Based on the fertility gradient approach The validity of these equations were tested by conducting nine follow up trials of maize grain on three soil series of Entisol (Viz.Karwali, Rahuri and Akole),three soil series of Inceptisol (Viz. Pather,Beed and Kolyachiwadi) and three soil series of Vertisol (Viz.Targaon,Ambulga and Babulgaon) during Kharif of 2010-11 Post Graduate Farm, Dairy farm and D block, M.P.K.V. Rahuri. The results revealed that the fertilizer application as per yield target 60 , 80 and $100 \mathrm{q} \mathrm{ha}^{-1}+10 \mathrm{tha}^{-1} \mathrm{FYM}$ to maize crop for validation on different soil series of Entisol (viz., Karwali, Rahuri and Akole), Inceptisol (viz., Pather, Beed and Kolyachiwadi) and Vertisol (viz., Targaon, Ambulga and Babulgaon) inrespect to soil $\mathrm{pH}$ and organic corbon content was higher in Vertisols (8.22 and $1.04 \%)$ and Inceptisols order (8.29 and $1.05 \%)$. Electrical conductivity of Vertisols and Entisols was higher (0.138 and $\left.0.135 \mathrm{dSm}^{-1}\right)$. Residual calcium carbonate content in Inceptisols and Vertisols was more (7.27 and $6.41 \%$ ). Addition of fertilizer application as per 60, 80 and $10 \mathrm{q} \mathrm{ha}^{-1}$ yield target $+10 \mathrm{t} \mathrm{ha}^{-1}$ FYM decreased the calcium carbonate content in all the soil series of Entisols, Inceptisols and Vertisols. Thus, fertilizer prescription equation for grain maize developed on Inceptisol can be suitable for Entisol and Vertisol soil order. However, it was more resembling with Vertisol than Entisol. 
cannot meet the total plant nutrient need of intensive agriculture. Hence, the integrated use of nutrient through inorganic fertilizers, organic manures and biofertilizers sources are need of the time. The need of Integrated Nutrient Management did not associate with the negative nutrient balance and the only chemical fertilizer alone nor can the organic sources exclusively achieve the production sustainability of soils. The Integrated Nutrient Management helps to restore and sustain soil fertility and crop productivity. It may help to check the emerging deficiencies of nutrients. Further, it brings economy and efficiency in fertilizer use, improvement in physical, chemical and biological environment of soils.

The targeted yield concept which is being widely followed since 1967 in All India Coordinated Research Project on STCR, which employs multiple regression equation to study the nutrient interactions. STCR approach appears to be a viable technology to sustain higher crop productivity and assure better soil quality under intensive agriculture system. The IPNS based STCR equations are useful for deciding the appropriate dose of chemical fertilizers in conjunction with the organic manures.

\section{Materials and Methods}

The field experiment with Maize crop was conducted during 2010-2011 on soil series of Entisol (viz- Karwali Rahuri, Akole), Inceptisol (viz- Pathar, Beed, Kolyachiwadi) and Vertisol (viz-Targaon, Ambulga, babulgaon) at cental campus, Mahatma Phule Krishi Vidyapeeth, Rahuri (M.S.). The experimental farm is located under semi-arid tropics with an annual rainfall varying from 307 to $619 \mathrm{~mm}$. The average annual precipitation during experiment period was $520 \mathrm{~mm}$. The soil of these sites is varying in their physical and chemical properties. The Entisols are recently formed shallow soils, no subsurface diagnostic horizon. The soil series of experimental plot were grouped under the order Entisol comprising members of loamy, isohyperthermic and taxonomically classified as Typic Ustorthents. The Inceptisol soil order has a cambic horizon with its upper boundry within $100 \mathrm{~cm}$ of the mineral soil surface and its lower boundry at a depth of $25 \mathrm{~cm}$ or more below the mineral soil surface. The soils of experimental plot were grouped under the order Inceptisol and taxonomically classified as Vertic Haplustepts. The soils were medium deep black. The Vertisol is classified taxonomically as Typic Haplusterts. The soils were deep black comprising members of clayey, montmorillonitic, isohyperthermic family of Typic Haplustert. The maize grain (cv- Rajashree) was sown by dibbling in experimental plot having four replications and six treatments. The experiment was laid out in split plot design with six treatments as $\mathrm{T}_{1}=$ Control (No fertilizer), $T_{2}=$ GRDF (120:60:40 $\left.\mathrm{N}: \mathrm{P}_{2} \mathrm{O}_{5}: \mathrm{K}_{2} \mathrm{O} \mathrm{Kg} \mathrm{ha}{ }^{-1}+10 \mathrm{t} \mathrm{FYMha}^{-1}\right), \mathrm{T}_{3}=\mathrm{As}$ per soil test, $\mathrm{T}_{4}=60 \mathrm{q} \mathrm{ha}^{-1}$ yield target $+10 \mathrm{t}$ $\mathrm{ha}^{-1} \mathrm{FYM}, \mathrm{T}_{5}=80 \mathrm{q} \mathrm{ha}^{-1}$ yield target $+10 \mathrm{tha}^{-}$ ${ }^{1} \mathrm{FYM}$ and $\mathrm{T}_{6}=100 \mathrm{q} \mathrm{ha}^{-1}$ yield target $+10 \mathrm{t}$ $\mathrm{ha}^{-1}$ FYM. The Farm Yard Manure is analysed for its nutrient contents. Maize grain was harvested and the soil samples were analysed for physicochemical properties and available macro and micro nutrients. The fertilizer prescription equations with and without FYM were developed for maize grain by using basic data NR, CS, CF and CFYM.

\section{Fertilizer prescription equations}

\section{i) Without FYM}

$\mathrm{FN}=4.51 \mathrm{X} \mathrm{T}-0.65 \mathrm{X} \mathrm{SN}$

$\mathrm{F} \mathrm{P}_{2} \mathrm{O}_{5}=1.93 \times \mathrm{X}-1.05 \mathrm{X} \mathrm{SP}$

$\mathrm{F} \mathrm{K}_{2} \mathrm{O}=2.57 \mathrm{X} \mathrm{T}-\mathrm{O} .16 \mathrm{X} \mathrm{SK}$

\section{ii) With FYM}

$\mathrm{FN}=3.88 \mathrm{X} \mathrm{T}-0.56 \mathrm{X} \mathrm{SN}-3.19 \mathrm{X} \mathrm{FYM}(\mathrm{t}$ $\mathrm{ha}^{-1}$ )

$\mathrm{FP}_{2} \mathrm{O}_{5}=1.91 \mathrm{X} \mathrm{T}-0.99 \times \mathrm{SP}-1.46 \mathrm{X} \mathrm{FYM}(\mathrm{t}$ 
ha $^{-1}$ )

$\mathrm{FK}_{2} \mathrm{O}=2.09 \mathrm{X} \mathrm{T}-0.13 \mathrm{X} \mathrm{SK}-1.08 \mathrm{X} \mathrm{FYM}$ $\left(\mathrm{t} \mathrm{ha}^{-1}\right)$

Where,

$\mathrm{FN}, \mathrm{FP}_{2} \mathrm{O}_{5}$ and $\mathrm{K}_{2} \mathrm{O}$ is fertilizer $\mathrm{N}, \mathrm{P}_{2} \mathrm{O}_{5}$ and $\mathrm{K}_{2} \mathrm{O}$ in $\mathrm{kg} \mathrm{ha}^{-1}$, $\mathrm{T}$ is yield target $\left(\mathrm{q} \mathrm{ha}{ }^{-1}\right)$ and SN,SP and SK are soil available N,P and $\mathrm{K}$ in $\mathrm{kg} \mathrm{ha}{ }^{-1}$ and FYM is farm yard manure in $\mathrm{tha}^{-1}$. The present investigation showsrepresents the grain yield, stover yield and fertilizer application to soil series of Entisol. Inceptisol and Vertisol.

\section{Physico-chemical properties}

\section{Entisols}

Recently formed shallow soils, no subsurface diagnostic horizon. The soil series of experimental plot were grouped under the order Entisol comprising members of loamy, isohyperthermic and taxonomically classified as Typic Ustorthents. The series includes soils of well drained and moderately permeable occurring on very gently slope of undulating topography. The soils have been interpreted as shallow and suitable for arable crops with proper management. The characteristics of soil series of Entisol soil order are as below (Table $1)$.

The texture of soil series of Karwali was clayey with low in available nitrogen $(150 \mathrm{Kg}$ $\left.\mathrm{ha}^{-1}\right)$, low in available phosphorus $(9.42 \mathrm{Kg}$ $\mathrm{ha}^{-1}$ ) and moderately high in potassium (224 $\left.\mathrm{Kg} \mathrm{ha}^{-1}\right)$. The soil was alkaline in reaction $(\mathrm{pH}$ 8.41).

The texture of soil series of Rahuri was clayey with low in available nitrogen $\left(150 \mathrm{Kg} \mathrm{ha}^{-1}\right)$, low in available phosphorus $\left(9.80 \mathrm{Kg} \mathrm{ha}^{-1}\right)$ and moderately high in potassium $(246 \mathrm{Kg}$ $\left.\mathrm{ha}^{-1}\right)$. The soil was moderately alkaline in reaction $(\mathrm{pH} 8.20)$.
The texture of soil series of Akole was clayey with low in available nitrogen $\left(125 \mathrm{Kg} \mathrm{ha}^{-1}\right)$, low in available phosphorus $\left(9.70 \mathrm{Kg} \mathrm{ha}^{-1}\right.$ ) and high in potassium (269 Kg ha ${ }^{-1}$ ). The soil was moderately alkaline in reaction ( $\mathrm{pH} 8.50$ ).

\section{Inceptisols}

A cambic horizon with its upper boundry within $100 \mathrm{~cm}$ of the mineral soil surface and its lower boundry at a depth of $25 \mathrm{~cm}$ or more below the mineral soil surface.

The soils of experimental plot were grouped under the order Inceptisol and taxonomically classified as Vertic Haplustepts. The soils were medium deep black.

The characteristics soil series of Inceptisol soil order are as below (Table 1). The texture of soil series of Pather was clayey with low in available nitrogen $\left(150 \mathrm{Kg} \mathrm{ha}{ }^{-1}\right)$, low in available phosphorus (8.04 $\mathrm{Kg} \mathrm{ha}^{-1}$ ) and Very high in potassium $\left(314 \mathrm{Kg} \mathrm{ha}^{-1}\right)$. The soil was alkaline in reaction ( $\mathrm{pH} 8.48)$.

The texture of soil series of Beed was clayey with low in available nitrogen $\left(163 \mathrm{Kg} \mathrm{ha}^{-1}\right)$, low in available phosphorus (11.09 $\mathrm{Kg} \mathrm{ha}^{-1}$ ) and Very high in potassium $\left(347 \mathrm{Kg} \mathrm{ha}^{-1}\right)$. The soil was alkaline in reaction $(\mathrm{pH} \mathrm{8.45)}$.

The texture of soil series of Kolyachiwadi was clayey with low in available nitrogen $(175 \mathrm{Kg}$ $\left.\mathrm{ha}^{-1}\right)$, low in available phosphorus $(8.87 \mathrm{~kg}$ $\left.\mathrm{ha}^{-1}\right)$ and very high in potassium $\left(370 \mathrm{~kg} \mathrm{ha}^{-1}\right)$. The soil was alkaline in reaction $(\mathrm{pH} \mathrm{8.65).}$

\section{Vertisols}

A layer of $25 \mathrm{~cm}$ or more thick with an upper boundry within $100 \mathrm{~cm}$ of the mineral soil surface, that has either slickensides or wedgeshaped peds that have their long axes tilled 10 to 60 degrees from the horizontal and a weighted average of 30 per cent or more clay in the fine earth fraction either between the 
mineral soil surface and a depth of $18 \mathrm{~cm}$ or in an Ap horizon, whichever is thicker, and 30 per cent or more clay in the fine earth fraction of all horizons between a depth of $18 \mathrm{~cm}$ and cracks that open and close periodically. The soil series of experimental plot were grouped under the order Vertisol and classified taxonomically as Typic Haplusterts. The soils were deep black comprising members of clayey, montmorillonitic, isohyperthermic family of Typic Haplusterts.

The series includes soils of well drained and slow permeability occurring on very gently slope (1-3 \%). The soils are developed on weathering of basalt, having very dark grayish brown clay, with medium, weak angular blocky structure. The characteristics soil series of Vertisol soil order are as below (Table 1).

The texture of soil series of Targaon was clayey with low in available nitrogen $(213 \mathrm{Kg}$ $\left.\mathrm{ha}^{-1}\right)$, low in available phosphorus $\left(11.92 \mathrm{Kg} \mathrm{ha}^{-1}\right)$ and Very high in potassium $\left(358 \mathrm{Kg} \mathrm{ha}^{-1}\right)$. The soil was alkaline in reaction $(\mathrm{pH} \mathrm{8.51)}$.

The texture of soil series of Ambulga was clayey with low in available nitrogen $(163 \mathrm{Kg}$ $\left.\mathrm{ha}^{-1}\right)$, low in available phosphorus $\left(12.47 \mathrm{Kg} \mathrm{ha}^{-1}\right)$ and Very high in potassium $\left(370 \mathrm{Kg} \mathrm{ha}^{-1}\right)$. The soil was alkaline in reaction $(\mathrm{pH} \mathrm{8.48)}$.

The texture of soil series of Babulgaon was clayey with low in available nitrogen (163 $\mathrm{Kgha}^{-1}$ ), low in available phosphorus $\left(9.70 \mathrm{Kg} \mathrm{ha}^{-1}\right)$ and Moderate in potassium $\left(179 \mathrm{Kg} \mathrm{ha}^{-1}\right)$. The soil was alkaline in reaction ( $\mathrm{pH} 8.40)$.

\section{Results and Discussion}

The $\mathrm{pH}$ and electrical conductivity in respect to soil order, soil series, fertilizer application and their interactions were assessed after harvest of grain maize crop.

\section{Soil pH}

Soil $\mathrm{pH}$ at harvest of grain maize crop was significantly influenced by the soil order, series, fertilizer application and their interactions (Table 2).

\section{Soil order}

Soil $\mathrm{pH}$ of the Inceptisols soil order was slightly higher (8.29) than the Vertisols (8.22) and Entisols (8.08). The soil series of Entisols order showed the Variation in soil $\mathrm{pH}$ whereas, the soil series of Inceptisols and Vertisols were not varied significantly for the $\mathrm{pH}$ of soil at harvest of grain maize. This might be associated with the salt accumulation by the clay content in both the soil orders are might be similar. The Entisols soil order is shallow in depth having good drainability than Vertisols and Incetisols hence less $\mathrm{pH}$ values.

\section{Fertilizer treatment}

The treatment of fertilizer application to grain maize significantly influenced the soil $\mathrm{pH}$ at harvest of grain maize. It was numerical less in fertilizer application as per yield target 60 , 80 and $100 \mathrm{q} \mathrm{ha}^{-1}$ with $10 \mathrm{t} \mathrm{ha}^{-1} \mathrm{FYM}$ in all the soil series of Entisols, Inceptisols and Vertisols soil orders.

Application of organics resulted in decline of soil $\mathrm{pH}$ from the original value of $8.41,8.20$ and 8.50 to $8.14,7.80$ and 8.30 in Karwali, Rahuri and Akole series of Entisols, decline of soil $\mathrm{pH}$ from the original value was observed from $8.48,8.45$ and 8.65 to $8.19,8.24$ and 8.44 in Pather, Beed and Kolyachiwadi series of Inceptisols and decline of soil $\mathrm{pH}$ from the original value of $8.51,8.48$ and 8.40 to 8.20 , 8.27 and 8.20 in Targaon, Ambulga and Babulgaon series of Vertisols. The considerable decline in soil $\mathrm{pH}$ was observed in fertilizer application in presence of Farm yard manure. This was probably due to the addition of organic fertilizers produced 
organic acids on their decomposition in soil which may temporarily reduce the soil $\mathrm{pH}$ values (Jayaprakash et al., 2004).

The noticeable decrease in $\mathrm{pH}$ may also be ascribed to increased retention of exchangeable bases and enhanced buffering capacity of the soil arising out of the farm yard manure addition. These results are in conformity with results of Acharya et al., (1988).

The decrease in soil $\mathrm{pH}$ at harvest grain maize by the fertilizer application as per 60,80 and $100 \mathrm{q} \mathrm{ha}^{-1}$ yield target with $10 \mathrm{t} \mathrm{ha}^{-1}$ FYM might be associated with formation of acids on decomposition of FYM in soil (Laxminarayana and Patiram, 2005).

\section{Soil series x Fertilizer treatment}

Interaction effects of soil series and fertilizer application treatments were non significant for soil $\mathrm{pH}$ and significant in soil series of Inceptisols soil order.

The interactions of soil series with fertilizer application treatment as per target 60,80 and $100 \mathrm{q} \mathrm{ha}^{-1}$ with $10 \mathrm{t} \mathrm{ha}^{-1}$ FYM recorded less values of soil $\mathrm{pH}$ than the fertilizer application without FYM application. The FYM has an ability to enhance the Cation exchange capacity. Solubilization of insoluble salts to solubilized form, production of organic acids to certain extents. These changes may reduced the soil $\mathrm{pH}($ Mann et al.,2006).

\section{Interactions within soil order}

The t-test values for interaction among the soil orders were negatively significant in Entisols vs Inceptisols, Entisols vs. Vertisols and positively significant Inceptisols vs. Vertisols. The t-test values indicated that the change in soil $\mathrm{pH}$ at harvest of grain maize might be because of variation in inherent soil characteristics of soil series and additive effect of chemical fertilizer and organic manures like FYM.

\section{Electrical conductivity}

The electrical conductivity of soil as influenced by soil order, series, fertilizer application and their interactions are reported in (Table 3). The change in electrical conductivity of soil showed the revere trend to that of observed in soil $\mathrm{pH}$ by the treatments of fertilizer application and similar trend by the soil series and interaction effects between soil series and fertilizer application.

\section{Soil series}

Application of organics resulted decrease in Electrical conductivity from the original value of $0.170,0.155$ and $0.156 \mathrm{dSm}^{-1}$ to 0.147 , 0.127 and $0.131 \mathrm{dSm}^{-1}$ in Karwali, Rahuri and Akole series of Entisols,0.164, 0.147 and 0.143 to $0.141,0.122$ and $0.121 \mathrm{dSm}^{-1}$ in Pather, Beed and Kolyachiwadi series of Inceptisols. and $0.160,0.168$ and 0.167 to $0.131,0.142$ and $0.143 \mathrm{dSm}^{-1}$ in Targaon, Ambulga and Babulgaon series of Vertisols.

\section{Fertilizer treatment}

The fertilizer treatment to grain maize grown on soil series of Entisols, Inceptisols and Vertisols were found to significant for electrical conductivity at harvest. It was increased in the treatment fertilizer application as per 60, 80 and $100 \mathrm{q} \mathrm{ha}^{-1}$ yield target with $10 \mathrm{t} \mathrm{ha}^{-1}$ FYM. This was only because of addition of FYM solubilize the salts in soils and naturally enhanced the electrical conductivity of soil. This decrease in EC of post-harvest soil samples might be due to leaching of salts due to rains and utilization of nutrients by the crop. The results are in accordance with the findings of Verma $e t$ al., (2010). 
Table.1 Physico-chemical properties of soil series of Entisol, Inceptisol, Vertisol

\begin{tabular}{|c|c|c|c|c|c|c|c|c|c|c|}
\hline \multirow{2}{*}{$\begin{array}{l}\text { Sr. } \\
\text { No. }\end{array}$} & \multirow[t]{2}{*}{ Particulars } & \multicolumn{3}{|c|}{ Entisol } & \multicolumn{3}{|c|}{ Inceptisols } & \multicolumn{3}{|c|}{ Vertisols } \\
\hline & & 范 & 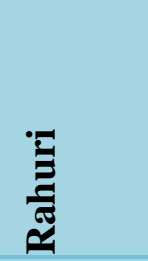 & $\frac{0}{\frac{\pi}{2}}$ & 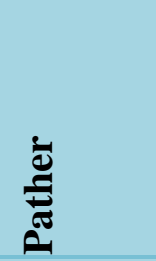 & تِّ & 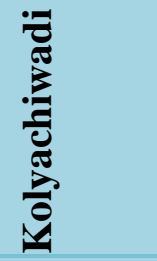 & 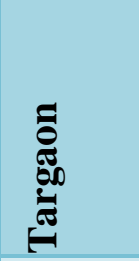 & 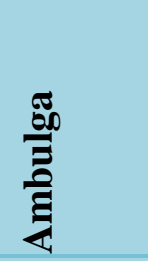 & 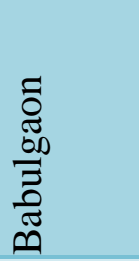 \\
\hline 1. & Sand & 27.1 & 23.9 & 28.5 & 20.2 & 22.3 & 37.2 & 5.7 & 3.7 & 15.9 \\
\hline 2. & Silt & 32.8 & 34.4 & 31.1 & 30.4 & 25.9 & 20.5 & 32.1 & 31.4 & 26.5 \\
\hline 3. & Clay & 40.1 & 41.7 & 40.4 & 49.4 & 51.8 & 42.3 & 62.2 & 64.9 & 57.6 \\
\hline 4. & Textural Class & Clayey & Clayey & Clayey & Clayey & Clayey & Clayey & Clayey & Clayey & Clayey \\
\hline 5. & $\begin{array}{l}\text { Bulk density } \\
\left(\mathrm{gcc}^{-1}\right)\end{array}$ & 1.33 & 1.32 & 1.32 & 1.32 & 1.33 & 1.33 & 1.34 & 1.33 & 1.34 \\
\hline 6. & $\begin{array}{l}\text { Moisture storage } \\
\text { capacity (mm) }\end{array}$ & 59.85 & 73.92 & 53.20 & 194.83 & 191.52 & 127.68 & 309.54 & 307.23 & 377.44 \\
\hline 7. & $\mathrm{pH}(1: 2.5)$ & 8.41 & 8.20 & 8.50 & 8.48 & 8.45 & 8.65 & 8.51 & 8.48 & 8.40 \\
\hline 8. & $\begin{array}{l}\mathrm{EC} \\
\left(\mathrm{dSm}^{-1}\right)\end{array}$ & 0.170 & 0.155 & 0.156 & 0.164 & 0.147 & 0.143 & 0.160 & 0.168 & 0.167 \\
\hline 9. & Organic Carbon (\%) & 0.67 & 0.57 & 0.54 & 0.63 & 0.66 & 0.52 & 0.51 & 0.60 & 0.64 \\
\hline 10. & $\mathrm{CaCO}_{3}(\%)$ & 6.00 & 5.00 & 7.25 & 8.75 & 5.75 & 10.25 & 10.00 & 6.00 & 6.50 \\
\hline 11. & $\begin{array}{l}\text { Available N } \\
\left(\mathrm{Kgha}^{-1}\right)\end{array}$ & 150 & 150 & 125 & 150 & 163 & 175 & 213 & 163 & 163 \\
\hline 12. & $\begin{array}{l}\text { Available P } \\
\left(\mathrm{Kghh}^{-1}\right)\end{array}$ & 9.42 & 9.80 & 9.70 & 8.04 & 11.09 & 8.87 & 11.92 & 12.47 & 9.70 \\
\hline 13. & $\begin{array}{l}\text { Available K } \\
\left(\text { Kgha }^{-1}\right)\end{array}$ & 224 & 246 & 269 & 314 & 347 & 370 & 358 & 370 & 179 \\
\hline 14. & Available $S\left(\mu g^{-1}\right)$ & 8.66 & 5.96 & 6.93 & 4.42 & 5.39 & 3.85 & 4.62 & 3.85 & 5.19 \\
\hline 15. & $\begin{array}{l}\text { Exchangeable Ca } \\
(\mathrm{cmol} \\
\left(\mathrm{p}+\mathrm{kg}^{-1}\right)\end{array}$ & 26.94 & 23.36 & 25.0 & 32.50 & 31.47 & 25.25 & 34.0 & 35.50 & 35.67 \\
\hline 16. & $\begin{array}{l}\text { Exchangeable } \mathrm{Mg} \\
\left(\mathrm{cmol}(\mathrm{p}+) \mathrm{kg}^{-1}\right)\end{array}$ & 13.50 & 12.67 & 13.34 & 15.64 & 14.44 & 15.88 & 20.50 & 21.12 & 19.0 \\
\hline 17. & $\begin{array}{l}\text { DTPA } \\
\text { Micronutrients } \\
\left(\mu \mathrm{g} \mathrm{g}^{-1}\right)\end{array}$ & & & & & & & & & \\
\hline I. & $\mathrm{Fe}$ & 4.71 & 4.52 & 4.64 & 4.32 & 5.69 & 3.28 & 3.96 & 5.58 & 5.02 \\
\hline II. & $\mathrm{Mn}$ & 5.45 & 2.52 & 3.33 & 5.87 & 3.68 & 2.57 & 3.11 & 2.98 & 2.75 \\
\hline III. & $\mathrm{Cu}$ & 4.82 & 2.22 & 2.39 & 4.78 & 2.67 & 2.45 & 2.89 & 2.24 & 2.54 \\
\hline IV. & $\mathrm{Zn}$ & 0.44 & 0.48 & 0.24 & 0.39 & 0.46 & 0.31 & 0.39 & 0.34 & 0.28 \\
\hline 18. & Available $\mathrm{B}\left(\mu \mathrm{g} \mathrm{g}^{-1}\right)$ & 0.39 & 0.41 & 0.40 & 0.41 & 0.40 & 0.39 & 0.38 & 0.43 & 0.40 \\
\hline 19. & $\begin{array}{l}\text { Available Mo } \\
\left(\mu \mathrm{g} \mathrm{g}^{-1}\right)\end{array}$ & 0.090 & 0.086 & 0.089 & 0.115 & 0.119 & 0.110 & 0.120 & 0.118 & 0.126 \\
\hline
\end{tabular}


Table. $2 \mathrm{pH}$ of soil as influenced by soil orders, series and treatments at harvest

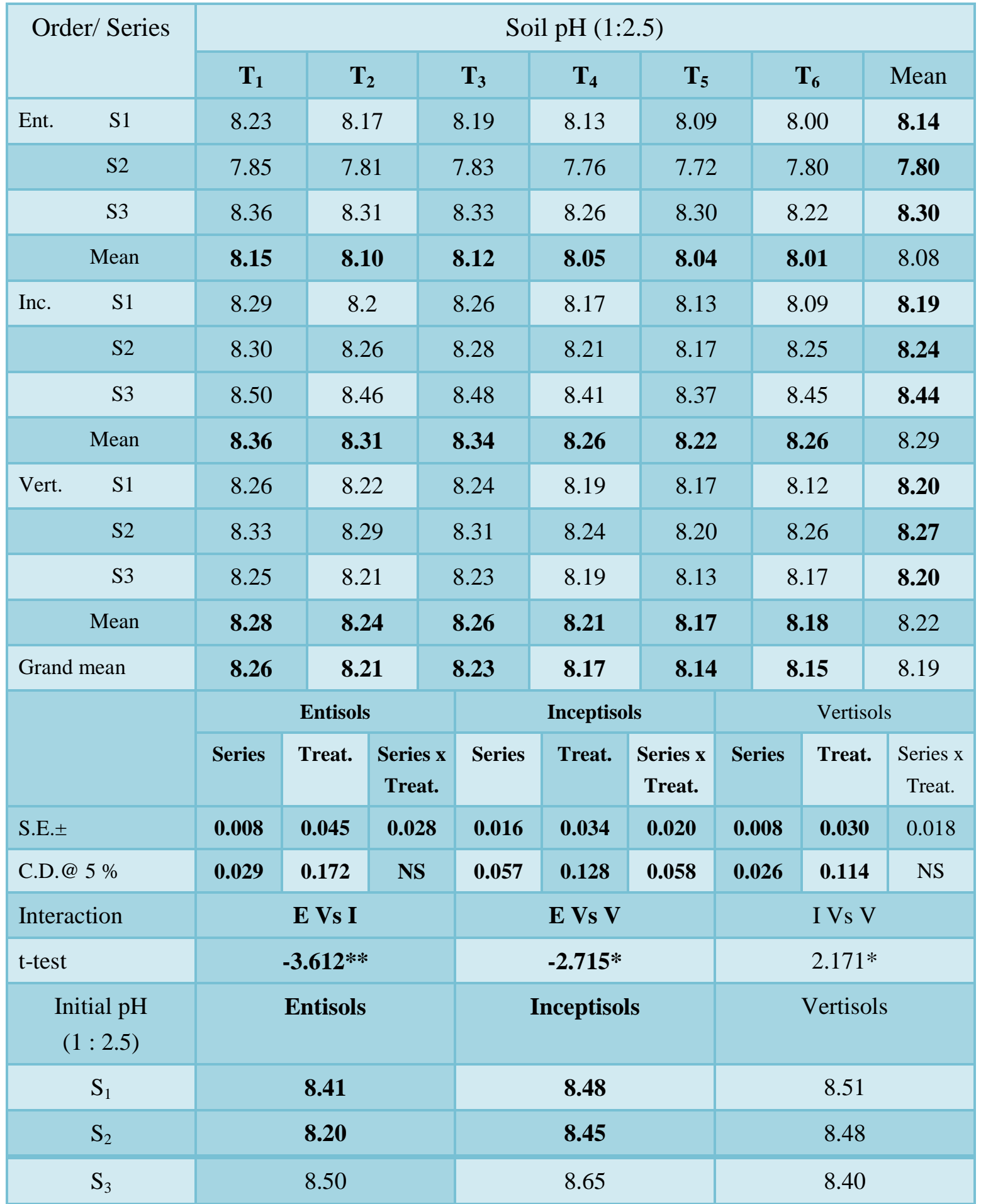


Table.3 Electrical Conductivity of soil as influenced by soil orders, series and treatments at harvest

\begin{tabular}{|c|c|c|c|c|c|c|c|c|c|c|}
\hline \multirow{2}{*}{\multicolumn{2}{|c|}{ Order/ Series }} & \multicolumn{9}{|c|}{ Electrical Conductivity $\left(\mathrm{dS} \mathrm{m}^{-1}\right)$} \\
\hline & & $\mathbf{T}_{1}$ & \multicolumn{2}{|c|}{$\mathbf{T}_{2}$} & $\mathbf{T}_{3}$ & $\mathbf{T}_{4}$ & \multicolumn{2}{|l|}{$\mathbf{T}_{5}$} & $\mathbf{T}_{6}$ & Mean \\
\hline \multirow[t]{4}{*}{ Ent. } & S1 & 0.137 & \multicolumn{2}{|c|}{0.148} & 0.142 & 0.145 & \multicolumn{2}{|l|}{0.152} & 0.156 & 0.147 \\
\hline & S2 & 0.119 & \multicolumn{2}{|c|}{0.121} & 0.123 & 0.126 & \multicolumn{2}{|c|}{0.133} & 0.138 & 0.127 \\
\hline & S3 & 0.122 & \multicolumn{2}{|c|}{0.129} & 0.125 & 0.133 & \multicolumn{2}{|c|}{0.137} & 0.141 & 0.131 \\
\hline & Mean & 0.126 & \multicolumn{2}{|c|}{0.133} & 0.130 & 0.135 & \multicolumn{2}{|c|}{0.141} & 0.145 & 0.135 \\
\hline \multirow[t]{3}{*}{ Inc. } & $\mathrm{S} 1$ & 0.134 & \multicolumn{2}{|c|}{0.142} & 0.136 & 0.139 & \multicolumn{2}{|c|}{0.145} & 0.149 & 0.141 \\
\hline & S2 & 0.113 & \multicolumn{2}{|c|}{0.119} & 0.116 & 0.122 & \multicolumn{2}{|c|}{0.127} & 132 & 0.122 \\
\hline & S3 & 0.113 & & & 0.117 & 0.122 & 0.125 & & .128 & 0.121 \\
\hline & Mean & 0.120 & & & 0.123 & 0.128 & 0.132 & & .136 & 0.128 \\
\hline Vert. & S1 & 0.123 & & & 0.127 & 0.129 & 0.136 & & 138 & 0.131 \\
\hline & S2 & 0.133 & 0. & & 0.137 & 0.143 & 0.148 & & 153 & 0.142 \\
\hline & S3 & 0.134 & 0. & & 0.137 & 0.145 & 0.148 & & .150 & 0.143 \\
\hline & Mean & 0.130 & & & 0.134 & 0.139 & 0.144 & & .147 & 0.138 \\
\hline Grand & nean & 0.125 & & & 0.129 & 0.134 & 0.139 & & .143 & 0.134 \\
\hline & & & Entiso & & & Inceptis & & & Vertis & \\
\hline & & Series & Treat. & $\begin{array}{c}\text { Series } \mathbf{x} \\
\text { Treat. }\end{array}$ & Series & Treat. & $\begin{array}{c}\text { Series } \mathbf{x} \\
\text { Treat. }\end{array}$ & Series & Treat. & $\begin{array}{c}\text { Series } \mathrm{x} \\
\text { Treat. }\end{array}$ \\
\hline S.E. \pm & & 0.001 & 0.004 & 0.002 & 0.001 & 0.004 & 0.002 & 0.001 & 0.005 & 0.003 \\
\hline C.D.@ & $5 \%$ & 0.003 & 0.014 & NS & 0.002 & 0.014 & NS & 0.003 & 0.017 & NS \\
\hline Intera & tion & & Vs I & & & E Vs V & & & I Vs & \\
\hline t-test & & & $921 \mathrm{~N}$ & & & $-1.055 \mathrm{~N}$ & & & -3.22 & \\
\hline & $\begin{array}{l}\text { ial EC } \\
\left.\mathrm{m}^{-1}\right)\end{array}$ & & ntisol & & & nceptis & & & Vertiso & \\
\hline & $S_{1}$ & & 0.170 & & & 0.164 & & & 0.160 & \\
\hline & $\mathrm{S}_{2}$ & & 0.155 & & & 0.147 & & & 0.168 & \\
\hline & $\mathrm{S}_{3}$ & & 0.156 & & & 0.143 & & & 0.167 & \\
\hline
\end{tabular}


Table.4 Organic carbon of soil as influenced by soil orders, series and treatments at harvest

\begin{tabular}{|c|c|c|c|c|c|c|c|c|c|c|}
\hline \multirow{2}{*}{\multicolumn{2}{|c|}{ Order/ Series }} & \multicolumn{9}{|c|}{ Organic carbon (\%) } \\
\hline & & $\mathbf{T}_{1}$ & \multicolumn{2}{|c|}{$\mathbf{T}_{2}$} & $\mathbf{T}_{\mathbf{3}}$ & $\mathbf{T}_{4}$ & \multicolumn{2}{|l|}{$\mathbf{T}_{5}$} & $\mathbf{T}_{6}$ & Mean \\
\hline \multirow[t]{4}{*}{ Ent. } & $\mathrm{S} 1$ & 0.84 & \multicolumn{2}{|c|}{1.21} & 0.93 & 1.18 & \multicolumn{2}{|l|}{1.27} & 1.24 & 1.11 \\
\hline & $\mathrm{S} 2$ & 0.67 & \multicolumn{2}{|c|}{0.83} & 0.70 & 0.90 & \multicolumn{2}{|l|}{1.05} & 1.17 & 0.89 \\
\hline & S3 & 0.65 & \multicolumn{2}{|c|}{0.84} & 0.71 & 0.90 & \multicolumn{2}{|l|}{1.10} & 1.15 & 0.89 \\
\hline & Mean & 0.72 & \multicolumn{2}{|c|}{0.96} & 0.78 & 0.99 & \multicolumn{2}{|l|}{1.14} & 1.19 & 0.96 \\
\hline \multirow[t]{4}{*}{ Inc. } & S1 & 0.78 & \multicolumn{2}{|c|}{1.08} & 0.93 & 0.99 & \multicolumn{2}{|l|}{1.22} & 1.35 & 1.06 \\
\hline & $\mathrm{S} 2$ & 0.75 & \multicolumn{2}{|c|}{0.93} & 0.82 & 1.11 & \multicolumn{2}{|l|}{1.18} & 1.27 & 1.01 \\
\hline & S3 & 0.73 & \multicolumn{2}{|c|}{1.06} & 0.86 & 1.27 & \multicolumn{2}{|l|}{1.29} & 1.35 & 1.09 \\
\hline & Mean & 0.75 & \multicolumn{2}{|c|}{1.02} & 0.87 & 1.12 & \multicolumn{2}{|l|}{1.23} & 1.32 & 1.05 \\
\hline Vert. & $\mathrm{S} 1$ & 0.63 & 0.5 & & 0.72 & 0.81 & 1.08 & & 1.20 & 0.90 \\
\hline & $\mathrm{S} 2$ & 0.78 & 0. & & 0.86 & 1.17 & 1.26 & & 1.38 & 1.07 \\
\hline & S3 & 0.78 & 1. & & 0.91 & 1.29 & 1.31 & & 1.41 & 1.14 \\
\hline & Mean & 0.73 & 1.1 & & 0.83 & 1.09 & 1.22 & & 1.33 & 1.04 \\
\hline Grand & nean & 0.73 & 1.0 & & 0.83 & 1.07 & 1.20 & & 1.28 & 1.02 \\
\hline & & & Entisol & & & Inceptis & & & Vertiso & \\
\hline & & Series & Treat. & $\begin{array}{c}\text { Series } x \\
\text { Treat. }\end{array}$ & Series & Treat. & $\begin{array}{c}\text { Series } x \\
\text { Treat. }\end{array}$ & Series & Treat. & $\begin{array}{c}\text { Series } x \\
\text { Treat. }\end{array}$ \\
\hline S.E. \pm & & 0.008 & 0.043 & 0.026 & 0.009 & 0.041 & 0.025 & 0.013 & 0.061 & 0.037 \\
\hline C.D.@ & $5 \%$ & 0.029 & 0.163 & 0.074 & 0.031 & 0.158 & 0.072 & 0.044 & 0.230 & 0.105 \\
\hline Intera & ion & & E Vs I & & & E Vs V & & & I Vs V & \\
\hline t-test & & & $1.921 \mathrm{NS}$ & & & $-1.055 N$ & & & $-3.227 *$ & \\
\hline Initi & $\mathrm{OC}(\%)$ & & Entisols & & & [nceptiso & & & Vertisol & \\
\hline & $S_{1}$ & & 0.67 & & & 0.63 & & & 0.51 & \\
\hline & $\mathrm{S}_{2}$ & & 0.57 & & & 0.66 & & & 0.60 & \\
\hline & $\mathrm{S}_{3}$ & & 0.54 & & & 0.52 & & & 0.64 & \\
\hline
\end{tabular}


Table.5 Calcium carbonate of soil as influenced by soil orders, series and treatments at harvest

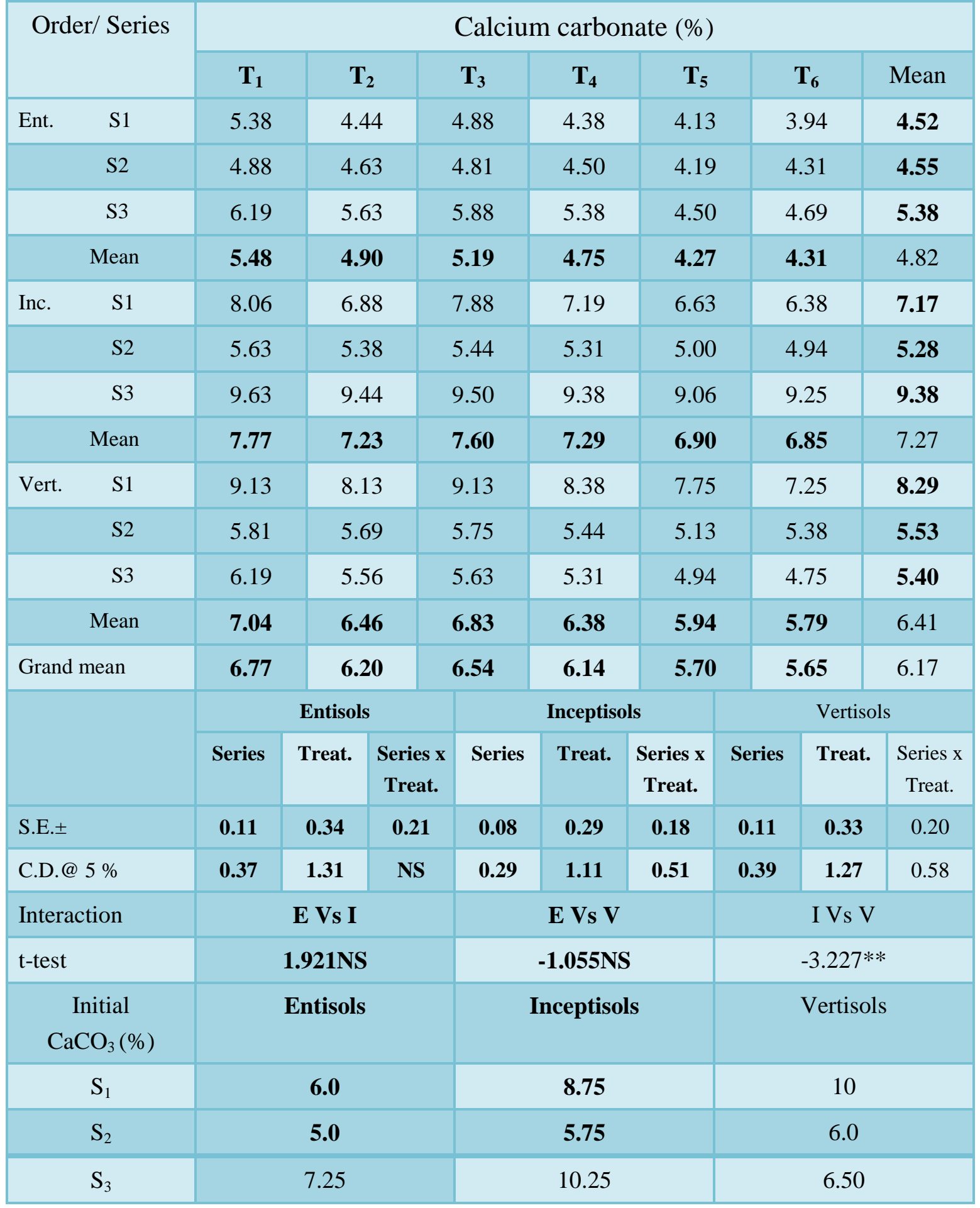


Table.6 Fertilizer application to follow up trials of grain maize grown on soil series of Entisols for validation

\begin{tabular}{|c|c|c|c|c|c|c|c|c|c|}
\hline \multirow[t]{2}{*}{$\begin{array}{l}\text { Sr. } \\
\text { No }\end{array}$} & \multirow[t]{2}{*}{$\begin{array}{l}\text { Nutrient/ } \\
\text { Treatment }\end{array}$} & \multirow[t]{2}{*}{$\begin{array}{l}\text { FYM } \\
\left(\text { tha }^{-1}\right)\end{array}$} & \multirow{2}{*}{$\begin{array}{l}\text { FYM } \\
(\mathrm{kg} \\
\left.\text { plot }^{-1}\right)\end{array}$} & \multicolumn{3}{|c|}{$\begin{array}{l}\text { Nutrients } \\
\left(\text { kgha }^{-1}\right)\end{array}$} & \multicolumn{3}{|c|}{$\begin{array}{l}\text { Fertilizers } \\
\left(\mathrm{kg} \mathrm{plot}^{-1}\right)\end{array}$} \\
\hline & & & & $\mathbf{N}$ & $\mathbf{P}_{2} \mathbf{O}_{5}$ & $\mathbf{K}_{2} \mathbf{O}$ & Urea & SSP & MOP \\
\hline & Karawali & & & & & & & & \\
\hline 1 & Control & 0 & 0 & 0 & 0 & 0 & 0.00 & 0.00 & 0.00 \\
\hline 2 & GRDF & 10 & 29.25 & 120 & 60 & 40 & 0.76 & 1.09 & 0.20 \\
\hline 3 & As per soil test & 0 & 0 & 150 & 75 & 40 & 0.95 & 1.37 & 0.20 \\
\hline 4 & $\begin{array}{l}60 \mathrm{q} \mathrm{ha}^{-1}+ \\
10 \mathrm{tha}^{-1} \mathrm{FYM}\end{array}$ & 10 & 29.25 & 117 & 90 & 85 & 0.74 & 1.65 & 0.42 \\
\hline 5 & $\begin{array}{l}80 \mathrm{q} \mathrm{ha}^{-1}+ \\
10 \mathrm{tha}^{1} \mathrm{FYM}\end{array}$ & 10 & 29.25 & 195 & 128 & 127 & 1.23 & 2.34 & 0.62 \\
\hline \multirow[t]{2}{*}{6} & $\begin{array}{l}100 \mathrm{q} \mathrm{ha}^{-1}+ \\
10 \mathrm{tha}^{-1} \mathrm{FYM}\end{array}$ & 10 & 29.25 & 272 & 166 & 169 & 1.72 & 3.03 & 0.82 \\
\hline & Rahuri & & & & & & & & \\
\hline 1 & Control & 0 & 0 & 0 & 0 & 0 & 0.00 & 0.00 & 0.00 \\
\hline 2 & GRDF & 10 & 29.25 & 120 & 60 & 40 & 0.76 & 1.09 & 0.20 \\
\hline 3 & As per soil test & 0 & 0 & 150 & 75 & 40 & 0.95 & 1.37 & 0.20 \\
\hline 4 & $\begin{array}{l}60 \mathrm{q} \mathrm{ha}^{-1}+ \\
10 \mathrm{th}^{-1} \mathrm{FYM}\end{array}$ & 10 & 29.25 & 117 & 90 & 83 & 0.74 & 1.64 & 0.40 \\
\hline 5 & $\begin{array}{l}80 \mathrm{q} \mathrm{ha}^{-1}+ \\
10 \mathrm{tha}^{1} \mathrm{FYM}\end{array}$ & 10 & 29.25 & 195 & 128 & 124 & 1.23 & 2.34 & 0.60 \\
\hline \multirow[t]{2}{*}{6} & $\begin{array}{l}100 \mathrm{q} \mathrm{ha}^{-1}+ \\
10 \mathrm{ha}^{-1} \text { FYM }\end{array}$ & 10 & 29.25 & 272 & 166 & 166 & 1.72 & 3.03 & 0.81 \\
\hline & Akole & & & & & & & & \\
\hline 1 & Control & 0 & 0 & 0 & 0 & 0 & 0.00 & 0.00 & 0.00 \\
\hline 2 & GRDF & 10 & 29.25 & 120 & 60 & 40 & 0.76 & 1.09 & 0.20 \\
\hline 3 & As per soil test & 0 & 0 & 150 & 75 & 20 & 0.95 & 1.37 & 0.10 \\
\hline 4 & $\begin{array}{l}60 \mathrm{q} \mathrm{ha}^{-1}+ \\
10 \mathrm{tha}^{-1} \mathrm{FYM}\end{array}$ & 10 & 29.25 & 131 & 90 & 80 & 0.74 & 1.64 & 0.40 \\
\hline 5 & $\begin{array}{l}80 \mathrm{q} \mathrm{ha}^{-1}+ \\
10 \mathrm{tha}\end{array}$ & 10 & 29.25 & 209 & 128 & 121 & 1.23 & 2.34 & 0.60 \\
\hline 6 & $\begin{array}{l}100 \mathrm{q} \mathrm{ha}^{-1}+ \\
10 t \mathrm{ha}^{-1} \text { FYM }\end{array}$ & 10 & 29.25 & 286 & 167 & 185 & 1.72 & 3.03 & 0.81 \\
\hline
\end{tabular}


Table.7 Fertilizer application to follow up trials of grain maize grown on soil series of Inceptisols for validation

\begin{tabular}{|c|c|c|c|c|c|c|c|c|c|}
\hline \multirow[t]{2}{*}{$\begin{array}{l}\text { Sr. } \\
\text { No }\end{array}$} & \multirow[t]{2}{*}{$\begin{array}{l}\text { Nutrient/ } \\
\text { Treatment }\end{array}$} & \multirow[t]{2}{*}{$\begin{array}{l}\text { FYM } \\
\left(\text { tha }^{-1}\right)\end{array}$} & \multirow{2}{*}{$\begin{array}{l}\text { FYM } \\
(\mathrm{kg} \\
\left.\text { plot }^{-1}\right)\end{array}$} & \multicolumn{3}{|c|}{$\begin{array}{l}\text { Nutrients } \\
\left(\mathrm{kgha}^{-1}\right)\end{array}$} & \multicolumn{3}{|c|}{$\begin{array}{l}\text { Fertilizers } \\
\left(\operatorname{kg~plot}^{-1}\right)\end{array}$} \\
\hline & & & & $\mathbf{N}$ & $\mathbf{P}_{2} \mathrm{O}_{5}$ & $\mathrm{~K}_{2} \mathrm{O}$ & Urea & SSP & MOP \\
\hline & Pather & & & & & & & & \\
\hline 1 & Control & 0 & 0 & 0 & 0 & 0 & 0.00 & 0.00 & 0.00 \\
\hline 2 & GRDF & 10 & 29.25 & 120 & 60 & 40 & 0.76 & 1.09 & 0.20 \\
\hline 3 & As per soil test & 0 & 0 & 150 & 75 & 20 & 0.95 & 1.37 & 0.10 \\
\hline 4 & $\begin{array}{l}60 \mathrm{q} \mathrm{ha}^{-1}+ \\
10 \mathrm{tha}^{-1} \mathrm{FYM}\end{array}$ & 10 & 29.25 & 117 & 92 & 95 & 0.74 & 1.67 & 0.46 \\
\hline 5 & $\begin{array}{l}80 \mathrm{q} \mathrm{ha}^{-1}+ \\
10 \mathrm{tha}^{1} \mathrm{FYM}\end{array}$ & 10 & 29.25 & 195 & 130 & 116 & 1.23 & 2.37 & 0.56 \\
\hline \multirow[t]{2}{*}{6} & $\begin{array}{l}100 \mathrm{q} \mathrm{ha}^{-1}+ \\
10 \mathrm{ha}^{-1} \text { FYM }\end{array}$ & 10 & 29.25 & 272 & 168 & 157 & 1.72 & 3.07 & 0.76 \\
\hline & Beed & & & & & & & & \\
\hline 1 & Control & 0 & 0 & 0 & 0 & 0 & 0.00 & 0.00 & 0.00 \\
\hline 2 & GRDF & 10 & 29.25 & 120 & 60 & 40 & 0.76 & 1.09 & 0.20 \\
\hline 3 & As per soil test & 0 & 0 & 150 & 75 & 20 & 0.95 & 1.37 & 0.10 \\
\hline 4 & $\begin{array}{l}60 \mathrm{q} \mathrm{ha}^{-1}+ \\
10 \mathrm{tha}^{-1} \mathrm{FYM}\end{array}$ & 10 & 29.25 & 110 & 89 & 69 & 0.70 & 1.62 & 0.34 \\
\hline 5 & $\begin{array}{l}80 \mathrm{q} \mathrm{ha}^{-1}+ \\
10 \mathrm{tha} \mathrm{l}^{1} \mathrm{FYM}\end{array}$ & 10 & 29.25 & 188 & 127 & 111 & 1.19 & 2.32 & 0.54 \\
\hline \multirow[t]{2}{*}{6} & $\begin{array}{l}100 \mathrm{q} \mathrm{ha}^{-1}+ \\
10 \mathrm{ha}^{-1} \mathrm{FYM}\end{array}$ & 10 & 29.25 & 265 & 165 & 153 & 1.68 & 3.01 & 0.74 \\
\hline & Kolyachiwadi & & & & & & & & \\
\hline 1 & Control & 0 & 0 & 0 & 0 & 0 & 0.00 & 0.00 & 0.00 \\
\hline 2 & GRDF & 10 & 29.25 & 120 & 60 & 40 & 0.76 & 1.09 & 0.20 \\
\hline 3 & As per soil test & 0 & 0 & 150 & 75 & 40 & 0.95 & 1.37 & 0.20 \\
\hline 4 & $\begin{array}{l}60 \mathrm{q} \mathrm{h}^{-1}+ \\
10 \mathrm{tha}^{-1} \mathrm{FYM}\end{array}$ & 10 & 29.25 & 103 & 91 & 88 & 0.65 & 1.66 & 0.43 \\
\hline 5 & $\begin{array}{l}80 \mathrm{qh} \mathrm{h}^{-1}+ \\
10 \mathrm{tha}{ }^{1} \mathrm{FYM}\end{array}$ & 10 & 29.25 & 181 & 129 & 108 & 1.14 & 2.36 & 0.53 \\
\hline 6 & $\begin{array}{l}100 \mathrm{q} \mathrm{ha}^{-1}+ \\
10 t \mathrm{ha}^{-1} \text { FYM }\end{array}$ & 10 & 29.25 & 258 & 167 & 150 & 1.63 & 3.05 & 0.73 \\
\hline
\end{tabular}


Table.8 Fertilizer application to follow up trials of grain maize grown on soil series of Vertisols for validation

\begin{tabular}{|c|c|c|c|c|c|c|c|c|c|}
\hline \multirow[t]{2}{*}{$\begin{array}{l}\text { Sr. } \\
\text { No }\end{array}$} & \multirow[t]{2}{*}{$\begin{array}{l}\text { Nutrient/ } \\
\text { Treatment }\end{array}$} & \multirow[t]{2}{*}{$\begin{array}{l}\text { FYM } \\
\left(\text { tha }^{-1}\right)\end{array}$} & \multirow{2}{*}{$\begin{array}{l}\text { FYM } \\
(\mathrm{kg} \\
\left.\text { plot }^{-1}\right)\end{array}$} & \multicolumn{3}{|c|}{$\begin{array}{l}\text { Nutrients } \\
\left(\mathrm{kgha}^{-1}\right)\end{array}$} & \multicolumn{3}{|c|}{$\begin{array}{l}\text { Fertilizers } \\
\left(\mathrm{kg} \mathrm{plot}^{-1}\right)\end{array}$} \\
\hline & & & & $\mathbf{N}$ & $\mathbf{P}_{2} \mathbf{O}_{5}$ & $\mathrm{~K}_{2} \mathrm{O}$ & Urea & SSP & MOP \\
\hline & \multicolumn{9}{|l|}{ Targaon } \\
\hline 1 & Control & 0 & 0 & 0 & 0 & 0 & 0.00 & 0.00 & 0.00 \\
\hline 2 & GRDF & 10 & 29.25 & 120 & 60 & 40 & 0.76 & 1.09 & 0.20 \\
\hline 3 & As per soil test & 0 & 0 & 150 & 75 & 30 & 0.95 & 1.37 & 0.15 \\
\hline 4 & $\begin{array}{l}60 \mathrm{q} \mathrm{ha}^{-1}+ \\
10 \mathrm{ha}^{-1} \mathrm{FYM}\end{array}$ & 10 & 29.25 & 131 & 90 & 80 & 0.52 & 1.60 & 0.33 \\
\hline 5 & $\begin{array}{l}80 \mathrm{q} \mathrm{ha}^{-1}+ \\
10 \mathrm{tha}^{1} \mathrm{FYM}\end{array}$ & 10 & 29.25 & 209 & 128 & 121 & 1.01 & 2.30 & 0.53 \\
\hline \multirow[t]{2}{*}{6} & $\begin{array}{l}100 \mathrm{q} \mathrm{ha}^{-1}+ \\
10 \mathrm{t} \mathrm{ha}^{-1} \mathrm{FYM}\end{array}$ & 10 & 29.25 & 286 & 167 & 185 & 1.50 & 3.00 & 0.74 \\
\hline & \multicolumn{9}{|l|}{ Ambulga } \\
\hline 1 & Control & 0 & 0 & 0 & 0 & 0 & 0.00 & 0.00 & 0.00 \\
\hline 2 & GRDF & 10 & 29.25 & 120 & 60 & 40 & 0.76 & 1.09 & 0.20 \\
\hline 3 & As per soil test & 0 & 0 & 150 & 75 & 20 & 0.95 & 1.37 & 0.10 \\
\hline 4 & $\begin{array}{l}60 \mathrm{q} \mathrm{ha}^{-1}+ \\
10 \mathrm{t} \mathrm{ha}^{-1} \text { FYM }\end{array}$ & 10 & 29.25 & 110 & 87 & 67 & 0.70 & 1.59 & 0.32 \\
\hline 5 & $\begin{array}{l}80 \mathrm{q} \mathrm{ha}^{-1}+ \\
10 \mathrm{t} \mathrm{ha}^{1} \text { FYM }\end{array}$ & 10 & 29.25 & 188 & 128 & 133 & 1.19 & 0.14 & 0.65 \\
\hline \multirow[t]{2}{*}{6} & $\begin{array}{l}100 \mathrm{q} \mathrm{ha}^{-1}+ \\
10 \mathrm{tha}^{-1} \mathrm{FYM}\end{array}$ & 10 & 29.25 & 265 & 167 & 175 & 1.68 & 3.04 & 0.85 \\
\hline & \multicolumn{9}{|l|}{ Babulgaon } \\
\hline 1 & Control & 0 & 0 & 0 & 0 & 0 & 0.00 & 0.00 & 0.00 \\
\hline 2 & GRDF & 10 & 29.25 & 120 & 60 & 40 & 0.76 & 1.09 & 0.20 \\
\hline 3 & As per soil test & 0 & 0 & 150 & 75 & 40 & 0.95 & 1.37 & 0.20 \\
\hline 4 & $\begin{array}{l}60 \mathrm{q} \mathrm{ha}^{-1}+ \\
10 \mathrm{t} \mathrm{ha}^{-1} \text { FYM }\end{array}$ & 10 & 29.25 & 110 & 90 & 91 & 0.70 & 1.64 & 0.44 \\
\hline 5 & $\begin{array}{l}80 \mathrm{q} \mathrm{ha}^{-1}+ \\
10 \mathrm{tha}^{1} \mathrm{FYM}\end{array}$ & 10 & 29.25 & 188 & 128 & 133 & 1.19 & 2.34 & 0.65 \\
\hline 6 & $\begin{array}{l}100 \mathrm{q} \mathrm{ha}^{-1}+ \\
10 t \mathrm{ha}^{-1} \text { FYM }\end{array}$ & 10 & 29.25 & 265 & 167 & 175 & 1.68 & 3.04 & 0.85 \\
\hline
\end{tabular}




\section{Soil series x Fertilizer treatment}

The interaction effects of soil series with fertilizer applications was found non significant for electrical conductivity of soil at harvest of maize crop. The non significant results indicated that the characteristics of soils of individual soil series viz., clay content, CEC, organic carbon, drainability, nutrient fixation, adsorption, desorption phenomenon plays dominant role in salt accumulation and release. Therefore, the interaction effects were non significant for electrical conductivity of soil (Mann et al. 2006).

\section{Interactions among soil order}

The t-test values for interaction effects within soil order were non significant in Entisols vs Inceptisols and Entisols vs Vertisols. It was negatively significant for Inceptisol vs Vertisols. The salt accumulation and salt solubilization mostly depend on physical, chemical and biological properties of individual soil order. Hence non significant results was observed for electrical conductivity, Tandon (1974).

\section{Organic carbon}

Soil order, soil series, fertilizer application and their interactions were significantly influenced the soil organic carbon at harvest of grain maize (Table 4).

\section{Soil order}

The average organic carbon content was numerically higher in Vertisols (1.04\%) followed by Inceptisols $(1.05 \%)$ and Entisols $(0.96 \%)$. The higher content of organic carbon in Inceptisols and Vertisols soil order might be associated with the higher clay content and organic matter content, Bharambe and Tomar (2004). Similarly in both the soil order there was increased biomass production of grain maize and might be also increased root biomass in soil. These root biomass was mixed in soil after harvest of grain maize which ultimately increased the organic carbon in soil. Similar results were also reported by Tolanur and Badanur (2003).

\section{Soil series}

The soil series of Vertisols and Inceptisols soil orders were recorded higher values of organic carbon than Entisols soil series irrespective of fertilizer application. This might be associated with increased root biomass of grain maize and higher clay content of the soil series.

\section{Fertilizer treatment}

The treatments of fertilizer application were found to record the higher amount of organic carbon in 60, 80 and $100 \mathrm{q} \mathrm{ha}^{-1}$ yield target + $10 \mathrm{tha}^{-1}$ FYM in all the soil order irrespective soil series. However, it was more in Vertisols and Inceptisols soil orders.

Application of farm yard manure resulted to increase in soil organic carbon from the original value of $0.67,0.57$ and 0.54 to 1.11 , 0.89 and $0.89 \%$ in Karwali, Rahuri and Akole series of Entisols, 0.63, 0.66 and 0.52 to 1.06, 1.01 and $1.09 \%$ in Pather, Beed and Kolyachiwadi series of Inceptisols and from $0.51,0.60$ and 0.64 to $0.90,1.07$ and $1.14 \%$ in Targaon, Ambulga and Babulgaon series of Vertisols respectively.

The beneficial increase in the organic carbon content of the soil was attributed to the addition of higher level of fertilizer and mineralization of the nutrients. The addition of FYM enhanced the microbial population and profused root growth increased the organic carbon content of soil. The results corroborate the findings of Jayaprakash et al., (2004). 
The increase in organic carbon content may be attributed to addition of organic materials and better root growth. The subsequent decomposition of these roots might have resulted in increased organic carbon content of soil. These observations are in agreement with the findings of Tolanur and Badanur (2003).

\section{Soil series x Fertilizer treatment}

The interaction effects of soil series and fertilizer application were significant for residual soil organic carbon. The increased soil organic carbon content by interaction effects was might be because of addition of organic manures to maize grain, higher clay content of soil series, organic matter content and addition of root biomass after harvest of maize grain.

\section{Interactions among the soil order}

The interaction effects between Entisols $\mathrm{x}$ Inceptisols and Entisols $\mathrm{x}$ Vertisols were negatively non significant. This was mainly because of less clay content and organic matter contents of Entisols. However, interactions between Inceptisols $\mathrm{x}$ Vertisols were positively significant for organic carbon content of soils. This was mainly atributed to clay content and organic matter of soils of both the soil order.

\section{Calcium carbonate}

Calcium carbonate content of soil at harvest of grain maize was significantly influenced by the soil order, soil series, fertilizer application and their interactions (Table 5).

\section{Soil order}

The residual $\mathrm{CaCO}_{3}$ content of Inceptisols soil order was higher $(7.27 \%)$ followed by Vertisols (6.41\%) and Entisols (4.82\%).

\section{Soil series}

The calcium carbonate content of soil series of Inceptisols was found to record the higher values than rest of soil series. This might be because of soils of these soil series are formed from parent material and clay minerals viz., calcite, dolomite (Acharya et al.1988).

\section{Fertilizer treatment}

The fertilizer application reduced the calcium carbonates in all the soil orders irrespective of soil series. It was more pronounced in fertilizer application as per 60,80 and $100 \mathrm{q}$ $\mathrm{ha}^{-1}$ yield target $+10 \mathrm{t} \mathrm{ha}^{-1}$ FYM.

Application of organics resulted decrease in calcium carbonate content from the original value of $6.0,5.0$ and 7.25 to $4.52,4.55$ and 5.38 in Karwali, Rahuri and Akole series of Entisols, 8.75, 5.75 and 10.25 to $7.17,5.28$ and 9.38 in Pather, Beed and Kolyachiwadi series of Inceptisols and 10, 6.0 and 6.50 to 8.29, 5.53 and 5.40 in Targaon, Ambulga and Babulgaon series of Vertisols.

The decreased in calcium carbonate content in the soil might be because of addition of sufficient organic matter in soil decomposes the calcium carbonate. Similar results were also reported by Goswami and Sahrawat (1982).

\section{Soil series x Fertilizer treatment}

The interaction effects of soil series and fertilizer applications were significant for calcium carbonate content of soils. Calcium carbonate content of all the soil series of Vertisols, Inceptisols and Entisols were significantly lower in interactions between soil series and 60,80 and $100 \mathrm{q} \mathrm{ha}^{-1}$ yield target with $10 \mathrm{t}$ FYM at harvest of maize. This might be associated with the addition of FYM. 


\section{Fertilizer application to Validation trials of maize grain on different soil orders}

For obtaining yield targets of 60, 80 and $100 \mathrm{q}$ $\mathrm{ha}^{-1}$, the fertilizer is calculated by using fertilizer prescription equation and the required amount of $\mathrm{N}, \mathrm{P}_{2} \mathrm{O}_{5}$ and $\mathrm{K}_{2} \mathrm{O}$ is applied through the chemical fertilizers. The amount of fertilizers (Urea, SSP and MOP etc.) applied is varied with the yield targets and treatments.

The fertilizer application to Kharif grain maize crop applied were calculated as per treatments on nutrient basis as $\mathrm{kg} \mathrm{ha}^{-1}$ quantity of fertilizers of respective nutrients per plot are presented in following tables 6,7 and 8 .

\section{References}

Acharya, C.L., Bishnoi, S.K. and Vaduvanshi, H.S. 1988. Effect of long term application of fertilizer and organic and inorganic amendments under continuous cropping on physical and chemical properties of Alfisol. Indian J. Agric. Sci. 58(7): 509-516.

Goswami, N.N. and Sahrawant, K.L. 1982. Nutrient transformation in soils macronutrients. Rev. Soil Res. India, Part-I, 1: 123-125.

Jayprakash, T.C., Naglikar, V.P., Pujari, B.T. and Shetty, R.A. 2004. Effect of organics and inorganics on soil properties and available nutrient status of soil after harvest of maize under irrigation. Karnataka J. Agric. Sci., 17(2):311-314.

Laxminarayana, K. and Patiram, 2005. Influence of inorganic, biological and organic manures on yield and nutrient uptake of groundnut (Arachis hyogaea) and soil properties. Indian J. Agric. Sci., 75(4): 218-221.

Mann, K.K., Brar, B.S. and Dhillon, N.S. 2006. Influence of long term use of farm yard manure and inorganic fertilizers on nutrient availability in a Typic Ustrochrept. Indian J. Agric. Sci. 76 (8):477-480.

Tandon, H.L.S. 1974. Dynamics of fertilizer nitrogen in Indian soils. Usage, transformation and crop removal of nitrogen. Fertil. News. 19 (7):3-11. Tolanur, S.I. and Badanur, V.P. 2003. Changes in organic carbon, available $\mathrm{N}$, $\mathrm{P}$ and $\mathrm{K}$ under Integrated use of organic manure and fertilizer on sustaining productivity of Pearl Millet-Pigeon pea System and fertility of an Inceptisols. J. Indian Soc.Soil Sci., 51(1):37-41.

Verma, G., Mathur A.K., Bhandari S.C. and Kanthalia, P.C. 2010. Long term effect of integrated nutrient management on properties of a Typic Haplustept under Maize-Wheat Cropping system. Soil Sci. Pl. Anal. 8 (5): 425-430.

Tolanur, S.I. and Badanur, V.P. 2003. Changes in organic carbon, available $\mathrm{N}, \mathrm{P}$ and $\mathrm{K}$ under Integrated use of organic manure and fertilizer on sustaining productivity of Pearl Millet-Pigeon pea System and fertility of an Inceptisols. J. Indian Soc.Soil Sci., 51 (1): 37-41.

Tomar,S.D.2004. Soil Test-Based Fertilizer Requirement for specific yield Targets of Wheat and Chickpea in Vertisols. J. Indian Soc.Soil Sci., 46 (3): 472-473.

\section{How to cite this article:}

Ghodke Pallavi Dipak, Kadlag Ashok Dattatray and Kokre Vishwajit Gorakhnath. 2018. Available Status of Soil as Influenced by Validation of Fertilizer Prescription Equations of Kharif Grain Maize on Different Soil Orders. Int.J.Curr.Microbiol.App.Sci. 7(07): 1109-1124. doi: https://doi.org/10.20546/ijcmas.2018.707.135 